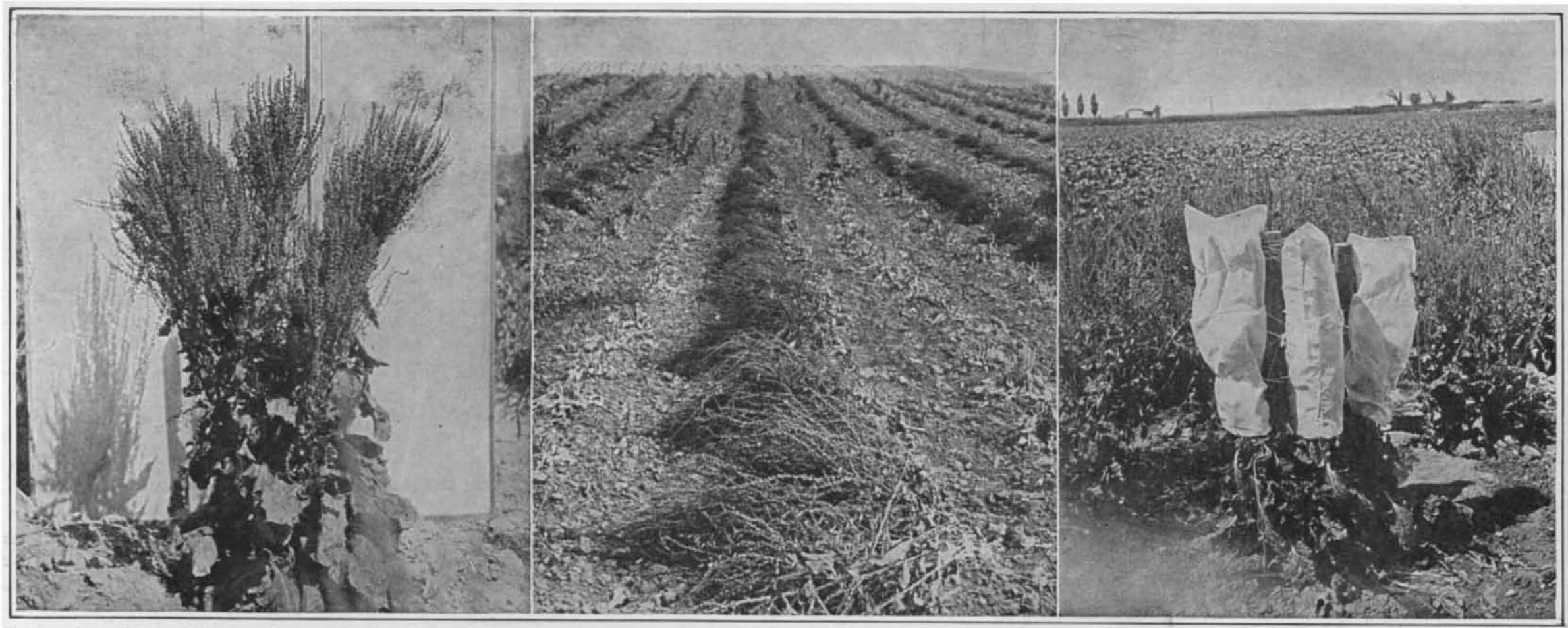

Specimen of the seed type of sugar-beet

\title{
Making America Self-Supporting
}

\section{Breaking Germany's Monopoly on Sugar-Beet Seed}

By Truman G. Palmer, Executive Secretary, U. S. Sugar Manufacturers' Association

MUCH has been written about the dependence of the upon Germany for many of the essential raw products used in manufacture. Instances are indeed not lacking where great manufacturing industries are more or less dependent upon foreign countries for some portion of their raw material; but that an industry established and operating in all the great temperate-zone nations of the world, and supplying the world with one-half of its pre-war sugar requirements, shouid be almost entirely dependent upon less than a dozen wealthy men in Saxony, is a fact as remarkable as it is deplorable.

Prior to the outbreak of war in Europe, the world produced approximately twenty million tons of sugar annually, about one-half of this being derived from sugar beets and the other half from sugar cane. While the sugar produced from these two plants is identical, there is a vast difference in the methods of propagation of the plants. The sugar cane of the tropics springs from the pame root year vame root year vation is necessary to produce a crop. In order to grow a crop of sugar beets, on the other hand, it is necessary to plant the seed each year, and the plants must be intensively cultivated throughout the growing season. Again, the wild beet is low in sugar content, and it is only after many decades of patient scientific work that a sufficient amount of sugar has been bred int it to make it a profitable crop. Inaruch as the tendento of the plant is to revert to it originl state of lowdency of the plant is to revert to it original state of low suga content, the work of the plant breeders is never ending, and sugar companies naturally purchase their seed from breeders of the highest established reputation. It so happens that the leading sugar-beet seed growers of the world are located in Saxony; this one province supplied nearly 70 per cent of the seed from which the world, in 1913-14, produced 9,784,000 tons of beet sugar. or one-halrits total produced $9,784,000$ ton of bet or one-hallits of the world's beet-sugar crop in the year mentioned was
produced from seed grown in Germany and by German firms which controlled the large production of Russia. Bearing the above facts in mind, one readily can appreciate the position of the American beet-sugar industry at the outbreak of war in Europe. The American beetsugar factories were importing about ninety-one per cent of their annual seed requirements from Germany and Austria, while every other country from which we imported seed was either directly involved in the war, or in directly affected by it. But upon the outbreak of war, conditions surrounding the importation of seed were entirely disrupted and the situation was the cause of grave concern to American producers. It was a particularly unfortunate time to be cut off from the usual supply, as seed stocks in the United States had neve been so low. The average New York wholesale price of granulated sugar for 1913 had dropped to 4.278 cent per pound, the lowest in history, and Congress had provided that the import duty on foreign sugar should be abolished on May 1st, 19i6, which would still further lower gloomy outlook, company managements had allowed their seed stocks to decline and when war was declared in 1914 and the price of sugar began to recover, some beet-sugar companies did not have a bag of seed on hand for their 1915 planting, others had but a small supply, and only a few were well provided for.

After the outbreak of war, the German and Austrian seed growers demanded payment in Rotterdam, upon delivery of railroad bills of lading. In the fall of 1914 the financial and industrial conditions were in such a chaotic state that it was found necessary to send a committee of beet-sugar manufacturers to Rotterdam, no only to arrange for payment at that port. but also to facilitate seed shipment. During their stay of practically two months. the committee finally succeeded in shipping between nine and ten million pounds of beet seed. In 1915, a een nine and tey million pounds of bet seed desired for 1916 planting in the United State amounted to from $14,000,000$ to $16,000,000$ pounds.
British blockade and German embargo had broken of business intercourse between the United States and Germany, except through diplomatic channeis. In negotiating for the importation of seed it was accordingly necessary to conduct all correspondence by cable through the Department of State. This correspondence brought an ultimatum from the German Government that the exportation of sugar-beet seed to the United State would be allowed only upon the condition that we first land foodstuffs or cotton at a German port, to the value of the seed to be exported. But Great Britain had position. After several months, during which time scores of cablegrams passed between Washington and Berlin, permit to export a meagre $1,650,0(10$ pounds was secured from Germany, "as a special consideration to the United States." Germany, however, reserved the right to designate the companies from whom the seed should be purchased and these in turn designated the American companies to whom it should be allotted.

But the difficulties did not end here. After securing permission of the German Government to purchase 15,000 bags of seed in that country, it then was necessary to get British consent to ship the seed from Rotterdam. This required many weeks of diplomatic correspondence between the United States and British Governments. While this was going on and several weeks after the German export permit had been granted, the State Department was informed that unless the money in payment for the seed was actually in Germany on a certain date, and the seed actually exported beyond the borders of that country, the permit would be revoked. The time limit set was so short that it was physically impossible for all the American beet-sugar producers to complete the financial arrangements, so one of the large companies stepped into the breach and guaranteed the entire amount, which was immediately cabled to Girmany by the express company. Due to this action, the (Concluded on page 5.58)

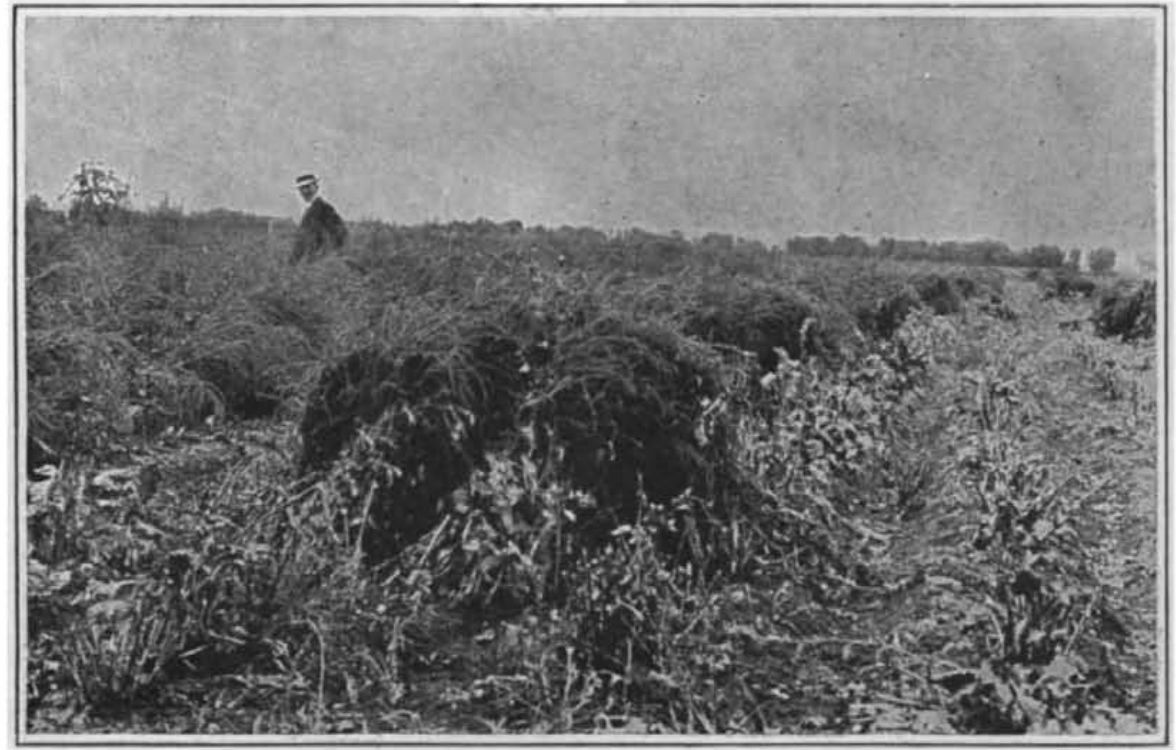

Shocks and standing plants of sugar-beet seed

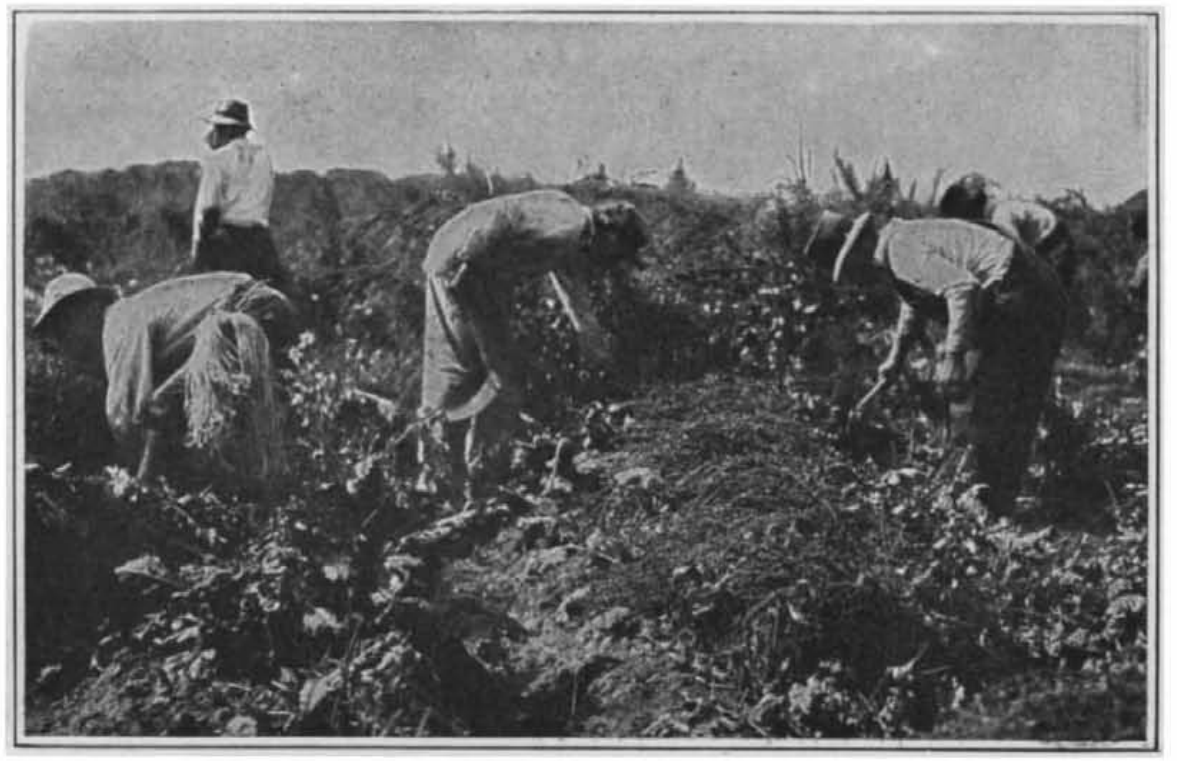

Cutting and tying the shocks of sugar-beet seed 


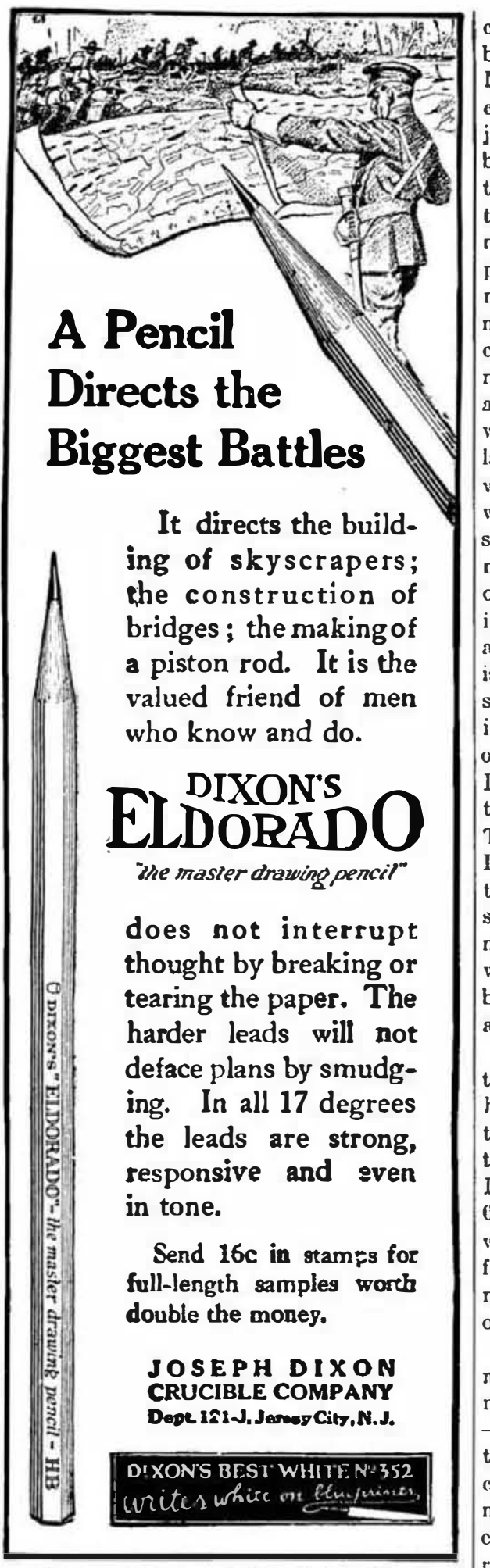

\section{Stop the Leaks Preserve your Roofs with

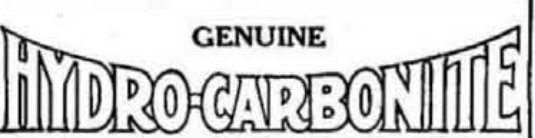
THE ORIGINAL ELASTIC ROOFING PAINT SEAB०O0TE PLASTIC ROOFING THE ORIGINAL ASBESTOS ROOFING CEMENT

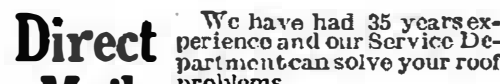
Mail

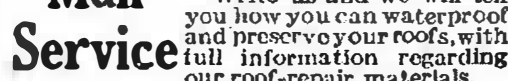
THE MONARCH PAINT CO. 1250 W. 70th St., Cleveland, Ohio

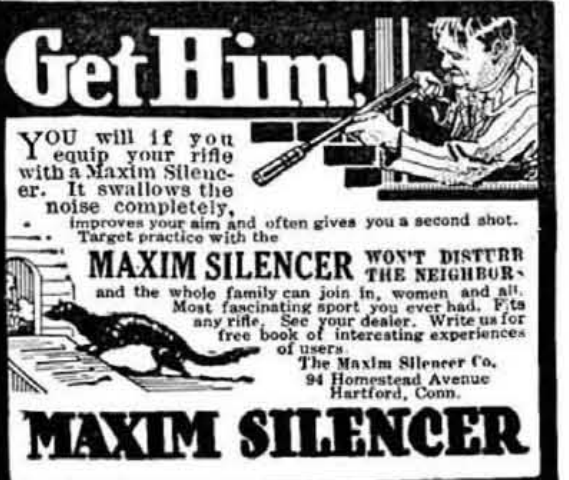

considered infected wounds at the very It is interesting to note that after all Many wounds, which come to us infected $\begin{aligned} & \text { much of our land needs phosphate fertil- } \\ & \text { izers more than potash, thus emphasizing }\end{aligned}$ lear up most marvelously, and new in- the need for soil analysis and intelligent juries treated early with the solution heal use of fertilizers regardicss of German by first intention." It is worth while propaganda. Our wheat is usually grown clling just how ambulatory cases are on soils wcll supplied with potash and our taken care of at this particular establish- corn crops are not likely to suffer. Potament, because it illustrates what can be toes, beets and turnips do need potash but prevented by prompt action even where it has been shown that 100 per cent could men labor in a dirty germ-laden environ- be carned on potash used in the potato bel manifestly, the walking patient of Wisconsin, for instance, even at the man abed. To quote, "A dressing is fertilizers. Then we have much unused pplied over the wounded area in such a potash-bearing land in the United States way that the denuded or exposed tissue which can be called upon, and in the last acration is free from pressurc. First, the analysis we need labor more than we do wound is thoroughly, but carefully, cleaned potash

ith Dakin's solution, either by spray or swabbing off with cotton. Pressure is meviously covering the un- it now in potash production in $\Lambda$ merica injured parts, to be included in the band- can be made the by-product and this in age, with vascline gauze. The bandage industries where production is on a tre is then applied and the patient is in- mendous scale, $i$. e., cement and iron. tructed to pour through the depression When our resources are tabulated who in the bandage where the opening of the shall say that we shall not win indepenriginal dressing appesrs, sufficicnt of the Daskin's solution, every two hours, to The paticnt is supplicd with a bottle of the Dakin solution sufficient to carry him over Dakin solution sufficient to carry him over
to the next dressing. When the injury is a small one, the dressing is applied as before mentioned, and the patient is supplice with a medicine dropper in addition to the bout the use of the solution."

The vaseline gauze is necdful because the hypochlorite of soda, while it does not hurt raw tissues does erode the skin, and the cuticle must be protected. According to the physician just quoted, he has found Dakin's solution entirely satisfactory in were lacerated fingers and compound fractures of bone where partially severed members, held only by the slightest piece integument, have becn saved.

In civil surgery, the Carrel-Dakin treatment of infected wounds has been of marked success in a pidle range of maladies - such as appendicitis, peritonitis, masation is daily widening. Thus insidiou micro-organisms are being dealt with reducer accordingly, and the patient is returned to health and strength with minimum of mutilation. Not only that, but an aitcrmath of reinfection is effectually prevented and recovery achieved in a remarkably short while.

\section{Potash Independence}

(Concluded from page 5\%6)

plant juice or the use of kclp ash as such. Theoretically the blast furnace can be made to add to its usefulness by using tating the potash by the Cottrell system just as is done in the cement mills. 11 is (laimed that 76 pounds of potash per ton of iron can be oblained in this way.

tonnage that would produce!

Then there are many less important sources. Eighteen thousand tons of potash are cstimated as the amount anmually factories. Crude wool, of which 290,000,000 pounds was washed in 1914, contnins about $41 / 2$ per cent of polash and distillery slops carry a small amount. Banana slops carry a small amount. Banana
stalks have 10.46 per cent when dried duwn to 4 per cent moisture but the collection difficulties are obvious. The same
is true of tobacco stems, yiclding 5 to 6 per cent. Wood ashes, formerly so extensively bleached for potash, have varying amounts according to the kind of wood, the red oat being eredited with 24 per cent, the shestnut with 18 per cent and the dog wood with 28 per cent. In fact most vegetation holds some potassium in combination and the problem is orre of econornical collection and sepaThose using large amounts of Chilean nitrate of soda, have found mays for scparating from it the small amount of potassium nitrate it contains and, with the present consumption of nitric acid, this source may become valuable.
Making America Self-Supporting last ear of seed rolled over the German border into Holland on the day set for the this seed was furnished at the then existing contract price of eight cents per pound, in participate in the distribution, that they. paid their more fortunate compctitors surplus seed. Since that tirne, no further Germany. frnm Germany and Austria, the domestic Fortunately, a considerable quantity of Russian seed had becn left over from old ocks, on account of the decreased plantings. But as soon as the Kussian seed growers learned of the situation, the price of Kussian seed immerliately rose to three times its usual value. Instend of paying addition most of the Russian growers mandied full payment for the seed before leit their shipping stations, which are located in southwestern Russia, 6,000
miles from Vladivostock. The single track railway from Kieff to Vladivostock was at that time congested with war traflic and weeks. Notwithstanding this, American surar faetories assumed the risk and forwarded a million and a half dollars to
Russia without any positive assurance that the seet could be brought out.

Before the seed could be shipped out, w:Ls neccssary to secure export permits ler to obtain these the companies were crical Attaché in Ncw York, bonds for mnifying the Russian Government against ils reêxportation after arrival in United States. On these bonds the proximstely $\$ 20,000$ in premiums. After months of delny, involving the sending he seed began to mowe, but it was not hat some of it rear after it was purchased Jast year, on acicount of the clanotic conlitions existing in Russia, the lack of became ever more acute; but af ter montlis of negotiation the beet-sugar companics supply forthe 1918 planting. But in view of the fact that the Germans have invaded the sugar-beet sced districts of Russia, any foreign secd for next ycars' planting. l'rior to the outbreak of war in Europe, che had been done by the Amcrican seed, owing mainly to their antipathy to embarking on a new enterprise which rethe American companies which did not

Estopped from securing any further seed can beet-sugar companics were compelled mpelled to filc, with the liussian Com-

\section{Advertising Classified}

LATHES AND SMALL TOOLS Friction Disk Drill

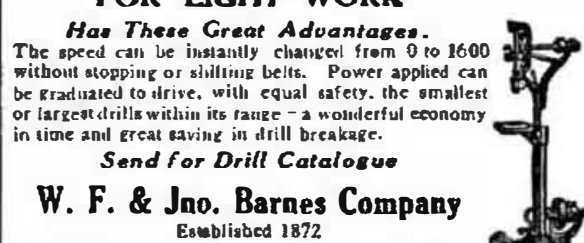
1999 Ruby Street Roctiabed 1872 Roch. Ulimoid
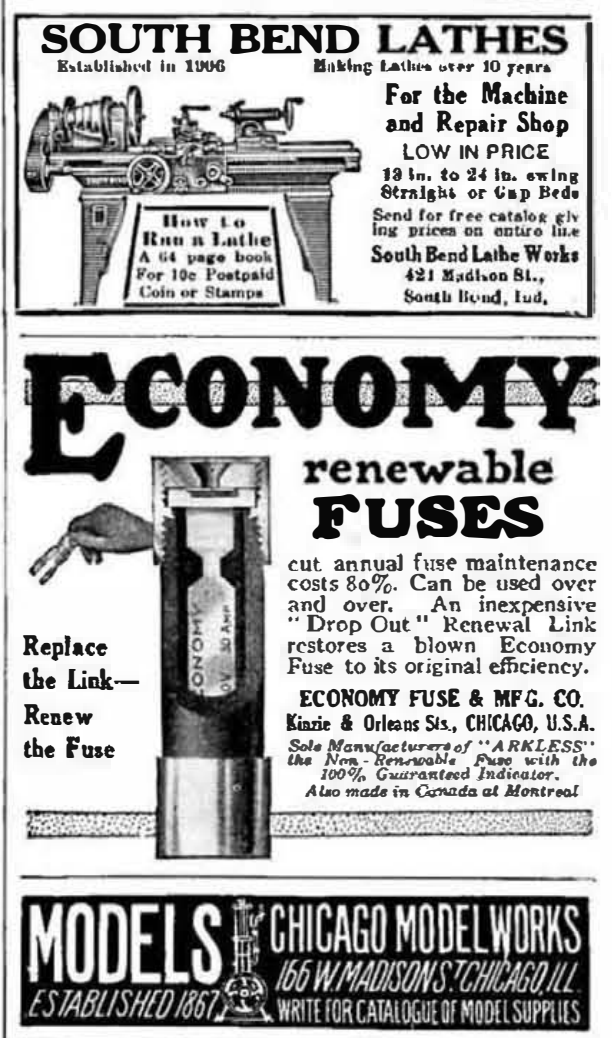

Ge MACIINES Corliss Engines, Brewers The VILTER MFG. CO.

s9s Clinton Street Milwauker, Wit.
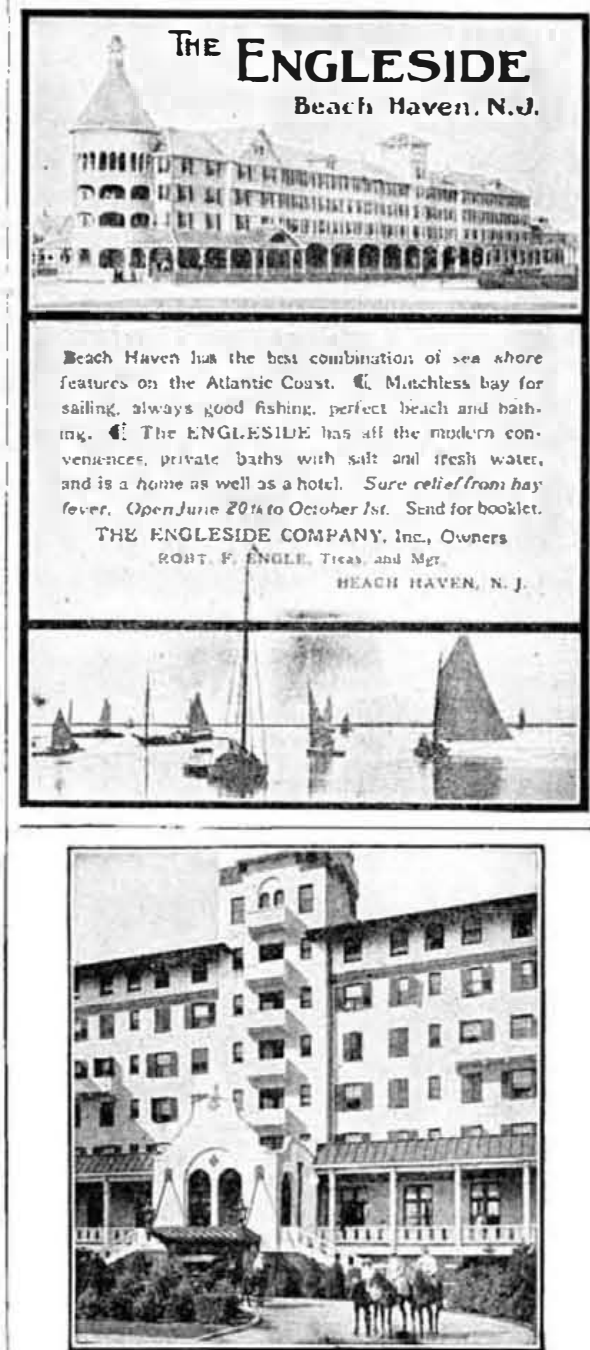

New Monterey Hotel North Asbury Park New Jersey a pacity 500 . All outside rooms. Hot and cold salt water in all bathrooms. White service. Orchestra.
Largest, most modern hotel on North Jersey Coast. NEW YORK BOOKING OFFICE, $8 \mathrm{~W}$. 40th $\mathrm{St}$. W. H. Wesswood, Representarive
SHERMAN DENNIS, Manager 
quires so much technical skill, the utiliza- versity," and these words are as true today tion of intricate scientific methods, and the as they were 300 years ago. Had the outlay of large sums of money in its in- American beet-sugar companies not passed auguration. The European sugar-beet throu the vicissitudes of the present seed growers have been engaged in the war, had they not met with almost unresearch extending over a period of nearly foreign-grown beet seed, it is more than a century they have succeeded in produc- likely that we should still have continued ing strains of seed of such high grade that to be dependent upon Germany for this it seemed impossible to increase the most important essential in the manustandard of quality appreciably. In addi- facture of beet sugar, and that that country tion, women and children do the bulk of would have continued to reap the benefits. the field work on European sugar-beet of this valuable market. As it is, with the seed farms; and the low wage paid to this energetic efforts being put forth by the class of labor has made it possible for domestic industry to produce at home all foreign growers to bring the cost of produc- of its seed requirements, the indications are tion to a point so low that, with our high- that when peace conditions again prevail, priced labor, we cannot produce sugar-beet Germany will awake to find that she has seed at anywhere near the cost at which it lost a valuable annual market for over can be grown in Europe. And so, while million dollars worth of sugar-beet seed some of the American factories had been a new and important American industry experimenting for several years in the will have been established, and the Amerigrowing of sugar-beet seed, but little com- can beet-sugar producers will have become mercial seed had been produced in this independent of foreign countries for thei country prior to the outbreak of war.

In this connection, it may be of interest to note that ordinarily five years of painstaking scientific work are required before a crop of commercial beets is harvested. For instance, let us suppose that in the spring of the first year the original selected seed is planted. The beet is a biennial; so in the fall those plants which p.ss a physical selection of foliage and root and a chemical test of the root are siloed for the winter, where they are kept from frost and heating. These are known as "mother" beets. In the spring of the second year these "mothers" are uncovered and after passing a second chemical test, are planted in the field and in the fall yield a crop which is known as "élite" seed. In the spring of the third year, the "élite" seed is planted closely in order to grow a crop of small beets, called "stecklinge," which are gathered in the fall and preserved in silos until the next spring. In the spring of the fourth year, the "stecklinge" are planted and in the fall they
produce a crop of commercial seed. This is planted the next spring, producing beets from which sugar is extracted in the fall, five tull years from the time the scientific work began. If the cycle started this spring it would be the fall of 1922 before the first definite returns were in.

Notwithstanding the intricacies of sugarbeet seed culture, and the tendency of the American beet-sugar manufacturers to import their seed from foreign concerns which had made this their sole business for many decades, after the difficulties of 1914 these manufacturers began to realize the precarious condition of their industry precarious condition of their industry long as it was dependent upon foreign
countries for its seed supply, especially during the continuance of the present war.

It therefore was decided, in the summer of 1915 , to take up in earnest the matter of producing their own seed in the United States. In the fall of that year a coöpStates. In the fall of that year a cooperative beet-seed company was organized with a capital of $\$ 100,000$, and several of
the individual beet-sugar companies which the individual beet-sugar companies which had conducted experiments in beet-seed these lines. It was well understood that under the most favorable conditions, it would be many years before sufficient home-grown seed could be produced to supply the annual requirements of the industry, but while climatic conditions wer unpropitious during the first year of the operation of the company, a fairly good start was made. The capital of the company has since been increased to $\$ 300,000$ and considerable land has been bought and rented for beet-seed culture with the results that practically one-third of the seed required for this year's planting was produced in the United States by the coöperative seed company and the individual sugar companies which have extended their work in the production of homegrown seed. While the cost of production is considerably higher than in Europe, there is reason to believe that strains of seed of a higher quality than the European strains, both as to tonnage per acre and sugar content, will be produced.

Three centuries ago Shakespeare penned convert the swamp into a public park and of the First Fabricated Ship
(Concluded from page 551)

hip before she was launched. The boilers ill be oil fired, the fuel being carried in e double bottom in more than sufficient quantity

We have spoken of the "Agawam" as a "fabricated" ship, which means that the majority of the work upon her has been done at various mills, foundries. machine work at the shipyard consisting merely in the erection of the ship with a minimum mount of plate and frame bending to be one at the yard. Approximately 27 teel mills, 56 fabricating plants, and 200 foundries, machine, pipe, foundry and duction of the parts to make up the finished ships. It is the belief of the company that, wen the yard is in full'swing, and the eel and general equipment are coming in on time, it will be possible to launch ship every two days.

The name, "Agawam," which was literally "Great Salt Meadows of the tlantic Coast.'

Collecting Rubbish by Motor Trucks (Concluded from page 552)

the scientific system under which the fleet of trucks is operated. Housewives place the shes and rubbish in cans, boxes, barrels and fer receptacles along the curbings and body of the trucks. In order to increase the load capacity the bodies of the trucks are built with 24-inch extension sides. This extra height permits each truck to haul 12 cubic yards on a single trip. Each day's work is divided into three sections and each section is in charge of a foreman who has four trucks and a crew of eight men under his supervision. There is a river for each truck, a man who lifts the ashes from the curbings and another helper who distributes the loads in the truck. The labor of loading is greatly simplified by special openings in the sides of the bodies through which the baskets, oaded simultaneously in three sections and the motors are kept running coninually from morning until night. Depite this the trucks have proven economical to operate and have earned a good After a truck is loaded, a heavy canvas cover is placed over the body to prevent the ashes falling to the pavement and being blown by the wind. The average distance rom the point of collection to the dump where the ashes are deposited, is six miles one way, and in making this haul the
trucks travel over definite routes through the city's most congested business thoroughfares.

The ashes are deposited in an old swamp adjoining the League Island Navy Yard, the extreme north end of Broad Street The corporation is paid for the ashes hauled to the dump by a wealthy Philadelphia
philanthropist who plans eventually to the words. "Sweet are the uses of ad-lplayground.
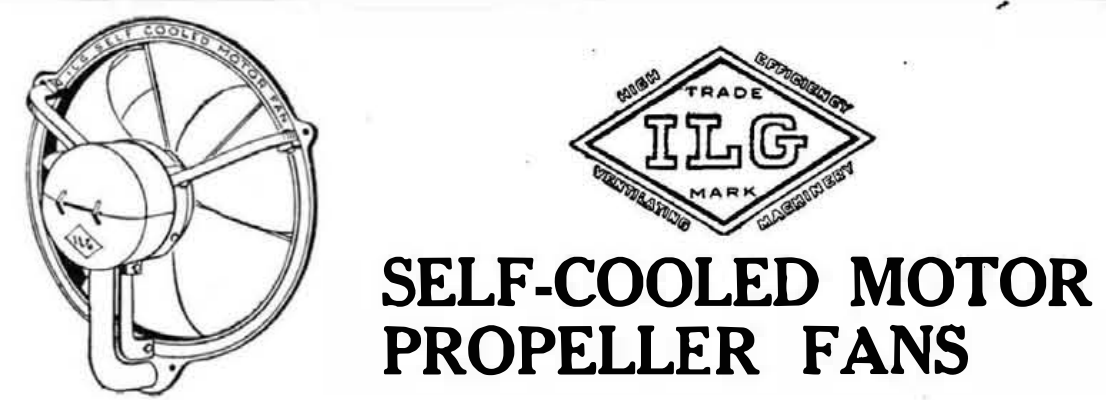

Can be used to exhaust heat, smoke, vapor, steam, acid fumes and can be used to blow in for cooling, drying, circulating.

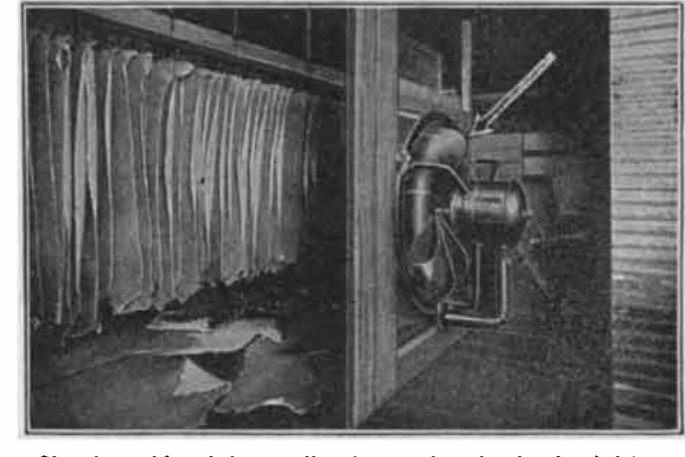

Showing self-cooled propeller jan used to d,y leather beltiny

We have solved ventilating, cooling and drying problems for all kinds of manufacturing plants.

11g Propeller Fans and Blowers are:
Low in power consumption
Quiet running
Durable
Covered by one guarantee as we build
Fan and Motor

Wie can make quick shipments in any quantity for any current or voltage.

Write for our catalogues on fans and blowers of all kinds.

We can send a man to see you from our nearest branch.

Ilg Electric Ventilating Co. Largest Exclusive Manufacturers of Fans and Blowers in the World 151 Whiting St. BRANCHES-ALL LARGE CITIES
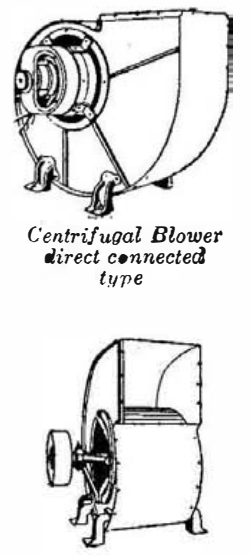

The Naval Reserve Force must enroll at once 1,000 men experienced in the operation and maintenance of gasoline engines.

This is an urgent call. The men are required for immediate duty. They will be rated as Machinist's Mates.

Age limits are eighteen to thirtyfive inclusive. Applicants must be American citizens. Draft registrants with letters from their local boards will be accepted.

Apply at Naval Reserve Enrolling Office, 51 Chambers Street, New York, or any Navy Recruiting Station. 
The Two-Man Tank

THE large British tank which is being Canadian Army to create interest and do its bit toward getting recruits, was lef standing on the street in Springfield, Mass. while the officers in charge went to lunch When they returned they found that the tank-known as "Miss Brittania"-had a little colt toddling by its side. The colt was vigorous and frisky and very imitative. The colt turned out to be the experimental "two-man tank," thus brought into public view for the first time, with the idea of comparing its performance with that of its big English mother and to see whether there was anything in the big one to offer a suggestion whereby the baby tank could be improved. The inventor is satisfied that the small machine will go anywhere the big one will go and many

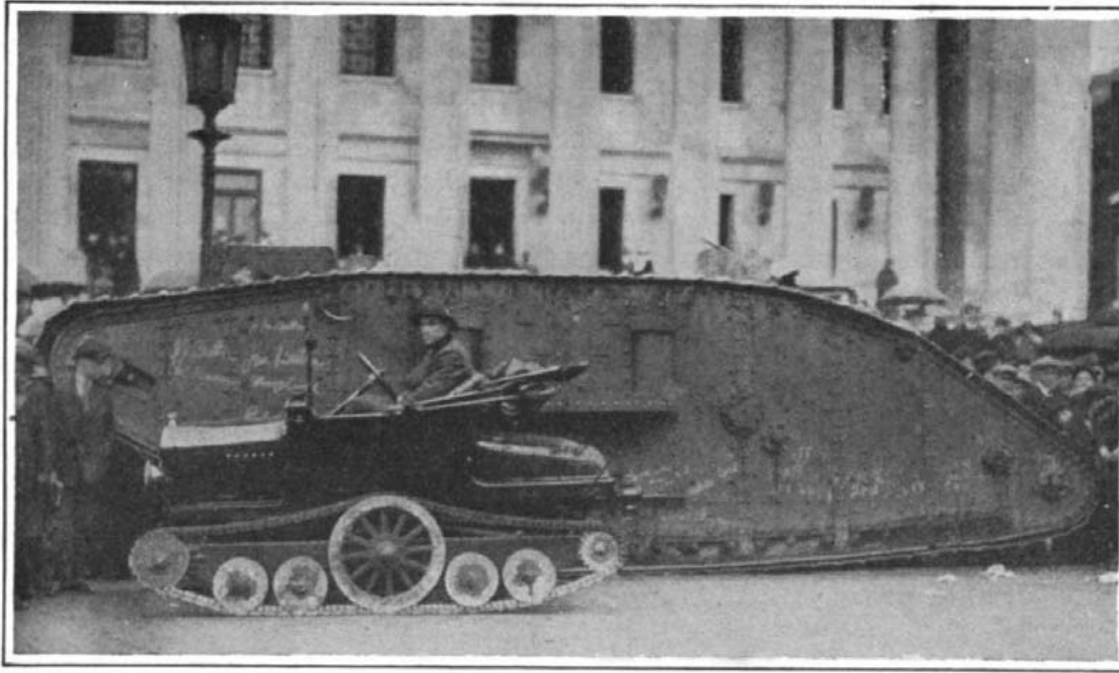

Mother and daughter-a British tank and its American offspring

wrecked. The important city of Nancy has been. under bombardment, not so fiercely as Rheims, but nevertbeless with very damaging effects.

Our illustration shows a 15 -inch shell which was fired from a long-range gun, but failed to explode. The threaded portion at the base of the ogival head proves that the shell was fitted with a false head or windshield, which was screwed in place. This, of course, was broken off when the shell struck. An interesting technical detail is the existence of three separate rifling bands at the base: the first, a narrow band; and the other two, more nearly approximating the normal size. There is no copper band near the head of the shell, as is the case with the shells that are falling in Paris; the centering of the forward part of the shell being secured by an enlargement of its diameter at the base of the nose. It will be noticed that this section of the shell was slightly scored by the rifling of the gun as the shell passed down the bore. Since "duds" are surface where they can be picked up.

Mr. Nanni suggests the employment of a buoy at the bottom of the shaft, connected to a cable wound on a reel. As the last buoyant safe leaves the shaft the buoy comes through, pulling the cable after it. This buoy not only serves to give greater buoyancy to the safes while they are in the submerged tube, but it marks the location of the sunken vessel for the benefit of anyone who wishes to undertake salvage work.

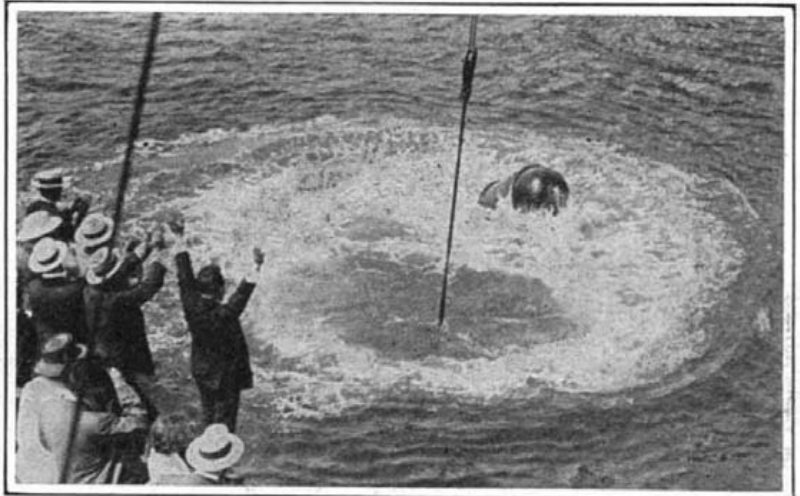

Buoyant safe coming to the surface after freeing itself from the shaft

German 15-inch Shell Thrown into Nancy

A FTER the disastrous defeat of a great German $A$ army in its attack on Nancy in 1914, the German were pushed back, and ultimately dug in permanently at a distance of several miles from this city. In accordance with their policy of attacking the civilian population as well as the armies of the enemy, they have emplaced batteries of heavy guns behind their own lines, and have engaged in a desultory bombardment of such French cities as they were able to reach. A most conspicuous and outrageous instance of this is the bombardment of Rheims, which, with its glorious cathedral, is now utterly 1 of Chicago, Ill., was given an official trial. And came through successfully, thereby fulfilling the predic tions of the inventor and proving to everyone that it is now possible to safeguard mail and treasure aboard steamers, even in these days of lurking U-boats.

Briefly, Mr. Nanni's floating safe is a short cylinder with rounded ends, as shown in one of the illustrations. The cylinder contains suitable buoyancy members, as well as a revolving arrangement of partitions so that any one of the radially arranged compartments may be brought in line with the single door, thus permitting mail, jewelry, money or other valuables to be deposited for safe keeping.

A number of these floating safes are placed one above the other in a long tube cr shaft extending down through several decks of the steamer. At each deck a door is provided, so as to give access to the safe opposite that deck. In this manner any safe can be reached with the same convenience as the conventional safe, and by turning the inner arrangement any compartment can be brought in line with the door. The tube has really two skins; the outer one, which is intact but for the exception of the doors at each deck, and an inner or perforated skin. The object of this double skin arrangement is at once evident: it permits water to pour down through the tube to the very bottom of the shaft, so as to give the proper buoyancy to the safes. The top of the shaft, extending through the upper deck, is provided with a buoyant removable cover which, in turn, has a suitable inlet for water Should the vessel be sunk, water would enter through the inlet in the buoyant removable cover of the shaft, and pour down between the skins and through the perforated inner wall to the safes. Soon the safes have sufficient buoyancy, and press up through the

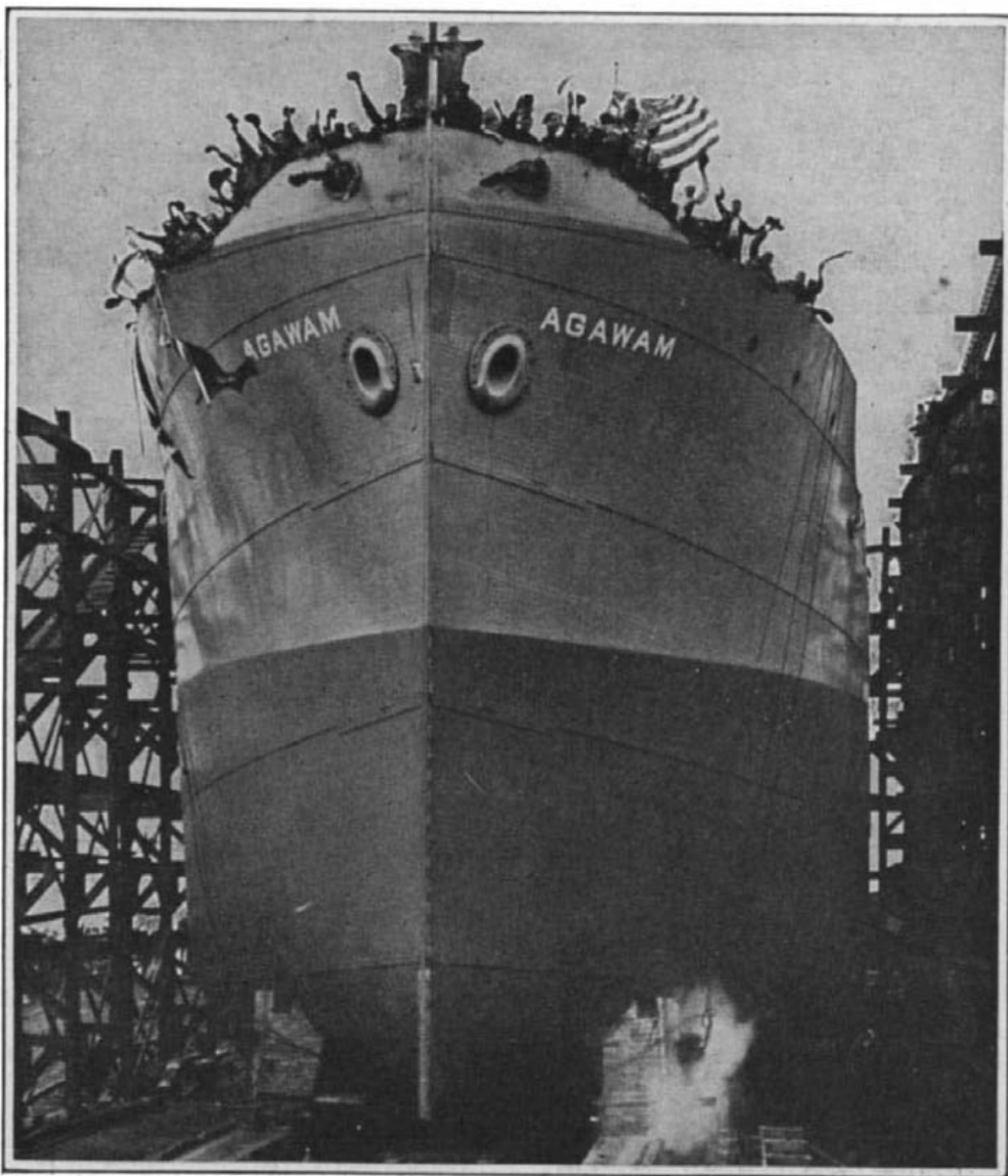

Launch of the "Agawam", first of the "fabricated" ships, at Newark Bay Shipyard

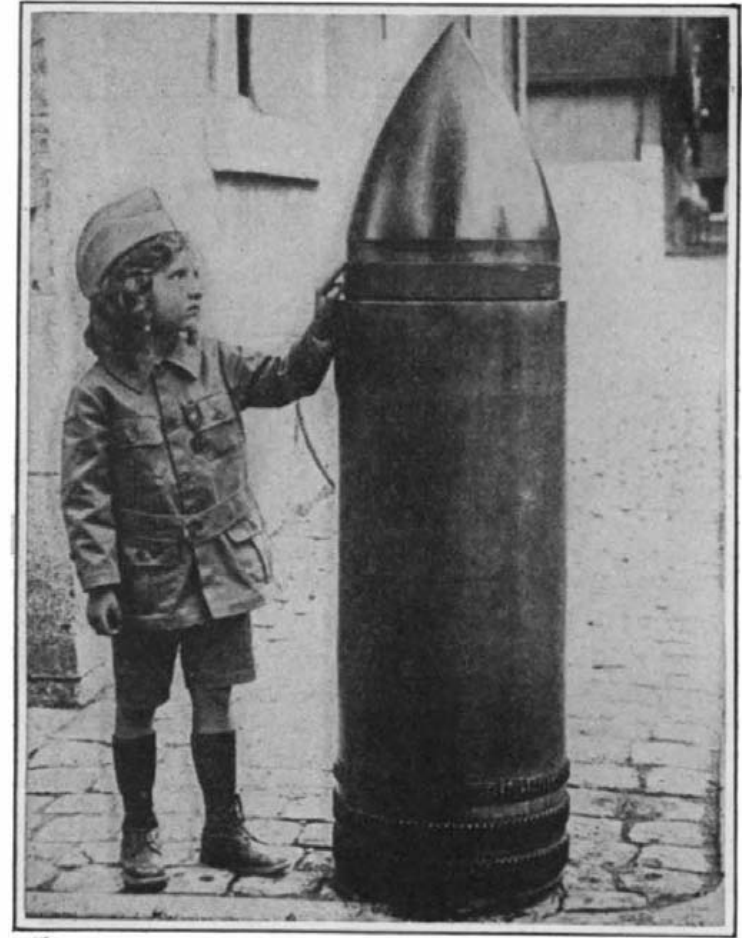

Unexploded 15" shell, thrown by the Germans

Launch of the First Fabricated Ship

$\mathbf{N}$ the autumn of last year we presented plans of the great shipbuilding yard, which was then under construction at Newark Bay, New York, for the Submarine Boat Corporation. This firm is the same that built the 550 standardized submarine chasers which have done excellent work in European The yard is equipped with 28 shipbuilding ways and with a wharf of sufficient capacity to accommodate the ships after they are launched and during the period of outfitting with engines, boilers, etc. At the present writing, the keels have been laid for 28 5,500-ton steel fabricated ships, which are in various stages of completion. The first of these was laid early in December, and the ship was launched on June 1st in the presence of Charles M. Schwab, Director-General of the Emergency Fleet Corporation, and Henry A. Carse and H. R. Sutphen, respectively the President and Vice-President of the Submarine Boat Corporation. The "Agawam," as she is called, is the first of 150 vessels of exactly the same size and type which this company is building for the Emergency Fleet Corporation of the United States Shipping Board. She will have a displacement, approximately, of 7,800 tons when fully loaded and a dead weight capacity of about 5,500 tons. She measures 343 feet on deck, and is 46 feet broad and 28 feet, 6 inches deep. The estimated maintained.speed of the vessel at sea, on a mean draft of approximately 23 feet, will be $101 / 2$ knots. The ship $w$ ill be driven by a Westinghouse steam turbine running at 3,600 revolutions per minute, which will drive a single screw propeller at 90 revolutions per minute through a Westinghouse reduction gear. Steam will be furnished by two Babcock and Wilcox water tube boilers, which, by the way, were installed in the (Concluded on page 559) 
quires so much technical skill, the utiliza- versity," and these words are as true today tion of intricate scientific methods, and the as they were 300 years ago. Had the outlay of large sums of money in its in- American beet-sugar companies not passed auguration. The European sugar-beet throug the vicissitudes of the present seed growers have been engaged in the war, had they not met with almost unresearch extending over a period of nearly foreign-grown beet seed, it is more than a century they have succeeded in produc- likely that we should still have continued ing strains of seed of such high grade that to be dependent upon Germany for this it seemed impossible to increase the most important essential in the manustandard of quality appreciably. In addi- facture of beet sugar, and that that country tion, women and children do the bulk of would have continued to reap the benefits. the field work on European sugar-beet of this valuable market. As it is, with the seed farms; and the low wage paid to this energetic efforts being put forth by the class of labor has made it possible for domestic industry to produce at home all foreign growers to bring the cost of produc- of its seed requirements, the indications are tion to a point so low that, with our high- that when peace conditions again prevail, priced labor, we cannot produce sugar-beet Germany will awake to find that she has seed at anywhere near the cost at which it lost a valuable annual market for over can be grown in Europe. And so, while million dollars worth of sugar-beet seed some of the American factories had been a new and important American industry experimenting for several years in the will have been established, and the Amerigrowing of sugar-beet seed, but little com- can beet-sugar producers will have become mercial seed had been produced in this independent of foreign countries for their country prior to the outbreak of war.

In this connection, it may be of interest to note that ordinarily five years of painstaking scientific work are required before a crop of commercial beets is harvested. For instance, let us suppose that in the spring of the first year the original selected seed is planted. The beet is a biennial; so in the fall those plants which p.ss a physical selection of foliage and root and a chemical test of the root are siloed for the winter, where they are kept from frost and heating. These are known as "mother" beets. In the spring of the second year these "mothers" are uncovered and after passing a second chemical test, are planted in the field and in the fall yield a crop which is known as "élite" seed. In the spring of the third year, the "élite" seed is planted closely in order to grow a crop of small beets, called "stecklinge," which are gathered in the fall and prethe spring of the fourth year, the "steckthe spring of the fourth year, the "stecklinge" are planted and in the fall they
produce a crop of commercial seed. This is planted the next spring, producing beets from which sugar is extracted in the fall, five tull years from the time the scientific work began. If the cycle started this spring it would be the fall of 1922 before the first definite returns were in.

Notwithstanding the intricacies of sugarbeet seed culture, and the tendency of the American beet-sugar manufacturers to import their seed from foreign concerns which had made this their sole business for many decades, after the difficulties of 1914 these manufacturers began to realize the precarious condition of their industry precarious condition of their industry long as it was dependent upon foreign
countries for its seed supply, especially during the continuance of the present war.

It therefore was decided, in the summer of 1915 , to take up in earnest the matter of producing their own seed in the United States. In the fall of that year a coöpStates. In the fall of that year a cooperative beet-seed company was organized with a capital of $\$ 100,000$, and several of
the individual beet-sugar companies which the individual beet-sugar companies which had conducted experiments in efforts along these lines. It was well understood that under the most favorable conditions, it would be many years before sufficient home-grown seed could be produced to supply the annual requirements of the industry, but while climatic conditions wer unpropitious during the first year of the operation of the company, a fairly good start was made. The capital of the company has since been increased to $\$ 300,000$ and considerable land has been bought and rented for beet-seed culture with the results that practically one-third of the seed required for this year's planting was produced in the United States by the coöperative seed company and the individual sugar companies which have extended their work in the production of homegrown seed. While the cost of production is considerably higher than in Europe, there is reason to believe that strains of seed of a higher quality than the European strains, both as to tonnage per acre and sugar content, will be produced.

Three centuries ago Shakespeare penned convert the swamp into a public park and of the First Fabricated Ship
(Concluded from page 551)

hip before she was launched. The boilers ill be oil fired, the fuel being carried in e double bottom in more than sufficient quantity

We have spoken of the "Agawam" as a "fabricated" ship, which means that the majority of the work upon her has been done at various mills, foundries. machine work at the shipyard consisting merely in the erection of the ship with a minimum mount of plate and frame bending to be one at the yard. Approximately 27 steel mills, 56 fabricating plants, and 200 foundries, machine, pipe, foundry and duction of the parts to make up the finished ships. It is the belief of the company that, wen the yard is in full'swing, and the eel and general equipment are coming in time, it will be possible to launch ship every two days.

The name, "Agawam," which was literally "Great Salt Meadows of the tlantic Coast.'

Collecting Rubbish by Motor Trucks (Concluded from page 552)

the scientific system under which the fleet of trucks is operated. Housewives place the shes and rubbish in cans, boxes, barrels and fer receptacles along the curbings and body of the trucks. In order to increase the load capacity the bodies of the trucks are built with 24-inch extension sides. This extra height permits each truck to haul 12 cubic yards on a single trip. Each day's work is divided into three sections and each section is in charge of a foreman who has four trucks and a crew of eight men under his supervision. There is a river for each truck, a man who lifts the ashes from the curbings and another helper who distributes the loads in the truck. The labor of loading is greatly simplified by special openings in the sides of the bodies through which the baskets, oaded simultaneously in three sections and the motors are kept running coninually from morning until night. Depite this the trucks have proven economical to operate and have earned a good After a truck is loaded, a heavy canvas cover is placed over the body to prevent the ashes falling to the pavement and being blown by the wind. The average distance rom the point of collection to the dump where the ashes are deposited, is six miles one way, and in making this haul the
trucks travel over definite routes through the city's most congested business thoroughfares.

The ashes are deposited in an old swamp adjoining the League Island Navy Yard, the extreme north end of Broad Street The corporation is paid for the ashes hauled to the dump by a wealthy Philadelphia
philanthropist who plans eventually to the words. "Sweet are the uses of ad-lplayground.
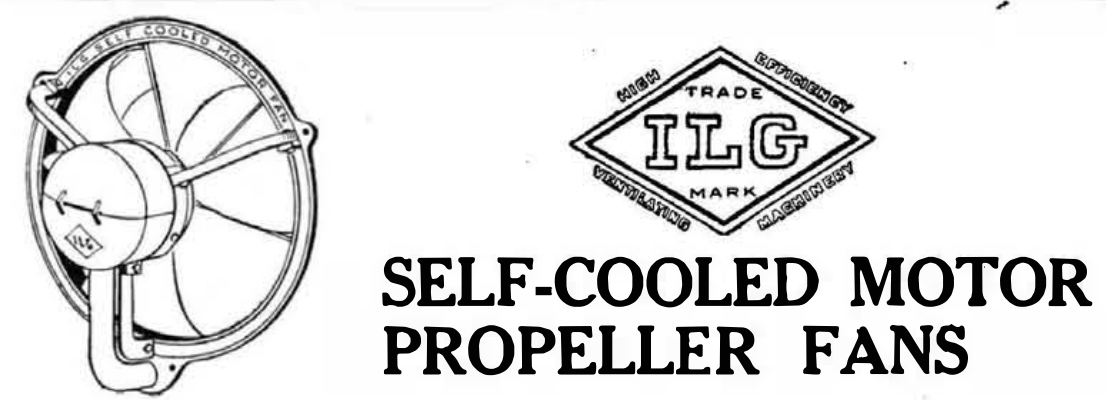

Can be used to exhaust heat, smoke, vapor, steam, acid fumes and can be used to blow in for cooling, drying, circulating.

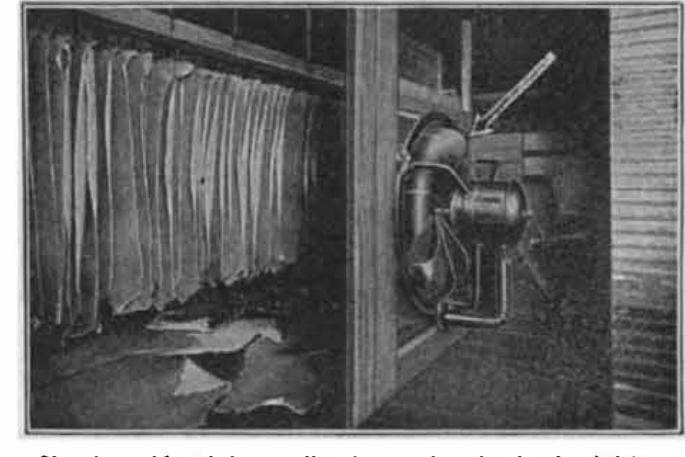

Showing self-cooled propeller jan used to d,y leather beltiny

We have solved ventilating, cooling and drying problems for all kinds of manufacturing plants.

11g Propeller Fans and Blowers are:
Low in power consumption
Quiet running
Durable
Covered by one guarantee as we build
Fan and Motor

Wie can make quick shipments in any quantity for any current or voltage.

Write for our catalogues on fans and blowers of all kinds.

We can send a man to see you from our nearest branch.

Ilg Electric Ventilating Co. Largest Exclusive Manufacturers of Fans and Blowers in the World 151 Whiting St. BRANCHES-ALL LARGE CITIES
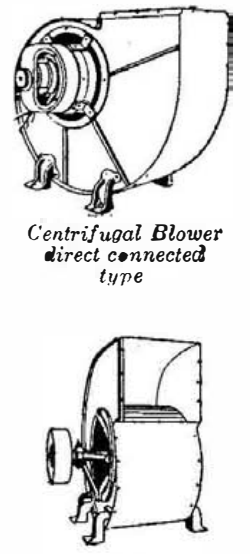

The Naval Reserve Force must enroll at once 1,000 men experienced in the operation and maintenance of gasoline engines.

This is an urgent call. The men are required for immediate duty. They will be rated as Machinist's Mates.

Age limits are eighteen to thirtyfive inclusive. Applicants must be American citizens. Draft registrants with letters from their local boards will be accepted.

Apply at Naval Reserve Enrolling Office, 51 Chambers Street, New York, or any Navy Recruiting Station. 